\title{
高解像度全球気候モデルによる 地球温暖化時の夏季アジアモンスーン \\ ASIAN SUMMER MONSOON UNDER THE GLOBAL WARMING USING A HIGH-RESOLUTION ATMOSPHERIC GENERAL CIRCULATION MODEL
}

\author{
大楽浩司 $1 \cdot$ 江守正多 2 \\ Koji DAIRAKU and Seita EMORI \\ 1防災科学技術研究所 総合防災研究部門（† 305-0006 茨城県つくば市天王台3-1） \\ 2 国立環境研究所 大気圈環境研究領域（テ305-8506 茨城県つくば市小野川16-2）
}

\begin{abstract}
Results from time-slice ensemble experiments using a T106 AGCM revealed changes in the South Asian summer monsoon resulting from climate change. Model results under global warming conditions, which are consistent with previous studies, suggested more warming over land than over the ocean, a northward shift of lower tropospheric monsoon circulation, and an increase in mean precipitation during the Asian summer monsoon. The number of extreme daily precipitation events increased significantly. Increases in mean and extreme precipitation were attributed to greater atmospheric moisture content (a thermodynamic change). In contrast, dynamic changes limited the intensification of mean precipitation. Enhanced extreme precipitation over land in South Asia arose from dynamic changes rather than thermodynamic changes.
\end{abstract}

Key Words: South Asian Monsoon, Extreme Events, Global Warming, Hi-resolution climate model

\section{1. はじめに}

これまで地球温暖化の影響については，主に気温や降 水量などの平均値の変化について論じられてきた。 それ は，気候モデルによる地球温暖化実験の出力データが月 平均程度でしか提供されてこなかったことや, 気候モデ ルの出力を時間・日単位で検証可能な観測データが非常 に限られていること, 気候モデルの空間解像度が粗く, 台風や豪雨のようなメソスケールの現象が重要となって くる極端な現象の再現性, その温暖化時の変化につい て，十分な精度を持ち得なかったということがあった。 しかし, 健康や，防災，水資源管理，農業生産，生態系 において特に重要であるのは，熱波によってもたらされ る極端な高温日，台風や集中豪雨，長い乾燥期間といっ た極值現象の頻度や強度の変化であるという認識が強 まってきている．実際，世界各地における観測から降水 量, 気温の極值分布の変化が示唆されている ${ }^{1)}$.

非常に活発な大気・陸域間の熱・水循環に特徵づけら れるアジアモンスーン地域には，世界の $60 \%$ を越す人 口が集中している.アジアモンスーンの変動は洪水・渇 水を引き起こし, 地域経済や人々の生活に大きな影響を
及ぼす，気候変動は発展途上国の極端現象に対する脆弱 性を悪化させる可能性が強い ${ }^{2}$ ， それゆえ，人為起源の 排出ガスによって引き起こされる地球温暖化がアジアモ ンスーンへどのような影響を及ぼすのかということは, 非常に重大な関心事であり, 近い将来の適応策・緩和策 の指針を得るために，解析・予測を行うことが緊急に求 められている.

これまで温暖化時のアジアモンスーンに関して数多く の研究が行われてきた。例えば，海陸の熱的コントラス 卜の強まり ${ }^{3)}$ や, 海面水温が温まり水蒸気が増加する ${ }^{4}$ ことによって, 南アジア夏季モンスーンによる降水の増 加と，年々変動が強まることを示したものもあれば，対 流圈下層のモンスーン循環が北へシフトし, 温暖化した 大気中水蒸気量の増加によって夏季の降水が増加するこ とを示したものもある ${ }^{5,}$, 9, 7, 8). Douville ら ${ }^{9)}$ と May ${ }^{10)}$ は，モンスーン循環の弱まりと降水の増加を示した。

Mitchell と Johns ${ }^{11}$ は, エアロゾルによってモンスーン循 環が弱まる可能性があることを示している.

地球温暖化に対するアジアモンスーンの応答は，ア ジアの多くの人々の重大な関心事であるが, 数多くの研 究にもかかわらず，その応答は未だ明らかではない，ま 
た, 低解像度（空間解像度 $300 \mathrm{~km}$ 程度）の気候モデル には前述した制限があり, 特に夏季アジアモンスーンの 日降水量の変動や極值の変化に関してごく少数の研究し か行われていない 5), 12). 多くの研究者は, 平均的な南ア ジア夏季モンスーンの増加は, 主に大気中水蒸気量の増 加によって生じると論じている. しかしながら, 水蒸気 の増加によって説明できるのは変化の一部でしかない． また, 近年, 世界最高速・最大規模のスーパーコン ピュータである地球シミュレータが 2002 年に稼動し, 高解像度地球温暖化シミュレーションが可能となった。 本研究は, 高解像度全球気候モデルを用いて, 温暖化時 の南アジア夏季モンスーンの変化, 特に力学的変化と熱 力学的変化がその日降水の変化に対してどのように影響 を及ぼすかについての検討を行う。

\section{2. 数値モデルと数値実験}

数值モデルは，水平解像度T106（約1.1度グリッド）, 鉛直 56 層の高解像度全球大気モデル (CCSR/NIES/FRSGC AGCM) ${ }^{13)}$ を用い, 標準実験5本, $\mathrm{CO}_{2}$ 倍増実験7本のタイムスライスアンサンブル実験を 行った. それぞれのアンサンブルメンバーの積分期間は 20年である. アンサンブル実験によって，例えば降水の ような内部変動が大きい現象，特に頻度の少ない極值現 象の変化に関する統計的信頼性が増すことが期待される.

標準実験は二酸化炭素濃度を345ppmvに固定し，下部 境界条件には，1979年から1998年のハドレーセンターの 海水密接度と海面水温のデータセット ${ }^{14)}$ を用いた。 また, エアロゾルの排出データは，1979年から1996年の平均を 用いた．それぞれのアンサンブルメンバーは，数年間の スピンアップランから取った年初めの異なる初期条件を 用いた。

二酸化炭素を倍増（690ppmv）させた温暖化実験では 下部境界条件として，大気海洋結合モデル (CCSR/NIES/FRSGC GCM) によるIPCC IS92aシナリオ 実験，また，他機関の結合モデル (NCAR-CSM, NCARPCM, MPI, GFDL, CSIRO, CCC) によるSRES A2シナリ オ実験における温暖化時の海面水温のアノマリを上記八 ドレーセンターの海面水温データに足し合わせたものを 用いた．エアロゾルは，標準実験と同じデータを用いた。

標準実験のアンサンブル間のばらつきは，大気の内 部変動による不確実性を示し, $\mathrm{CO}_{2}$ 倍増実験のアンサン ブルは, 大気の内部変動と, 予測された海面水温による 外部強制力の違いから生じる不確害性を示寸ものである.

\section{3. 解析手法}

本研究では, アジアモンスーンの日降水の変化が気候
変動による力学的な場の変化によって生じるのか，それ とも同様の力学場が与えられた場合に生じることが期待 される降水特性が変化するのか，という観点で解析を行 う.

温暖化時の日降水の変化に対寸る力学的, 熱力学的な 影響を解析するために，500hPa高度における日単位の鈆

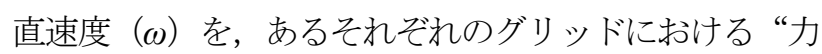
学的擾乱”を代表するものとして用いる ${ }^{15)}$, 16). 上昇流は ほとんどの場合積雲の中で起こるため, グリッドにおけ る上昇流は積雲パラメタリゼーションによるサブグリッ ドの雲中の鋁直流の強さを反映したものである. ある地 域における $500 \mathrm{hPa}$ 鉛直速度の確率密度関数を $\mathrm{Pr}_{\omega}$ とする.

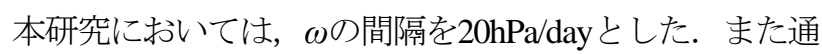
常の鉛直速度の定義とは異なり， $\omega$ の正の值を上昇流と し, 負の值を下降流とする. ある力学場が与えられた時 の日降水強度 $\left(R_{\omega}\right)$ を、それぞれの“ $\omega$ ビン”毎にコンポ ジットする. ある地域の平均降水量 $\bar{R}$ は，次のように 計算される.

$$
\bar{R}=\int_{-\infty}^{+\infty} \operatorname{Pr}_{\omega} R_{\omega} d \omega
$$

ここで，温室効果ガスの増加に関係した気候変化による 平均降水量の変化 $(\delta \bar{R})$ は,

$$
\begin{aligned}
\delta \bar{R}= & \int_{-\infty}^{+\infty} \delta \operatorname{Pr}_{\omega} R_{\omega} d \omega+\int_{-\infty}^{+\infty} \operatorname{Pr}_{\omega} \delta R_{\omega} d \omega \\
& +\int_{-\infty}^{+\infty} \delta \operatorname{Pr}_{\omega} \delta R_{\omega} d \omega
\end{aligned}
$$

と表すことが出来る.

式（1）の右辺第 1 項は, 鉛直運動の頻度や強さ（正 負の反転も含む）の変化によって生じる $\operatorname{Pr}_{\omega}$ の統計的重 みの変化による寄与を表す，すなわち，ある鉛直流 ( $\omega ）$ の時に期待される降水強度 $\left(R_{\omega}\right)$ は変化しないが, 力学的な場 $\left(\mathrm{Pr}_{\omega}\right)$ が変化することによって生じる降水 の変化である. この項を, 力学的変化 (dynamic change) とする. 第 2 項は, 力学的な場 $\left(\operatorname{Pr}_{\omega}\right)$ が変化 しなかった場合でも，ある鉛直流 $(\omega)$ の時に生じる降 水強度 $\left(R_{\omega}\right)$ の変化 (降水特性の変化) によって生じる 寄与を表す。この項を非力学的変化 (non-dynamic change) または熱力学的変化 (thermodynamic change) とする. これは, 主に大気中の水蒸気の変化による降水 特性の変化に相当寸る. 最後の第 3 項は, その両方の効 果による相関項 (co-variation) である.

ここでは, 大気中水蒸気の増加による水蒸気収束の強 まりは熱力学的効果として考慮され, 収束の強まりによ る水蒸気収束の強まりは力学的効果となる.

\section{4. 南アジア夏季モンスーンの平均場の変化}

図-1 (a) は，標準実験のアンサンブル平均の6月から9 月の降水分布と, $850 \mathrm{hPa}$ 高度の水平風を示寸. アンサン ブル実験の結果は, 観測で見られる夏季モンスーンの特 
(a)

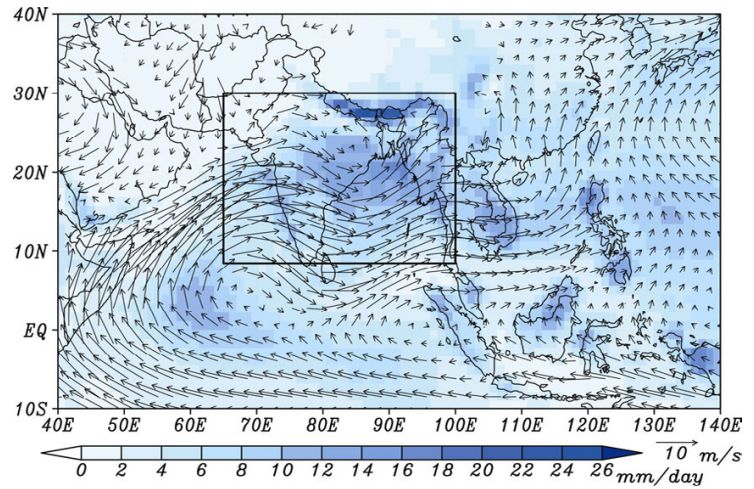

(c)

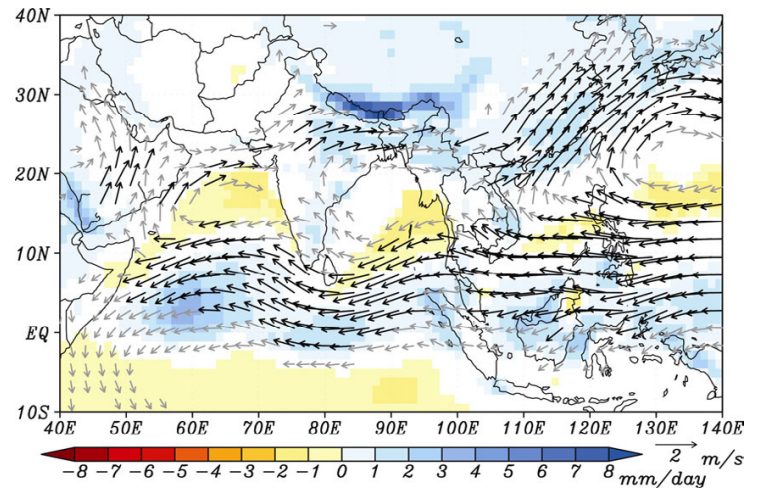

(b)

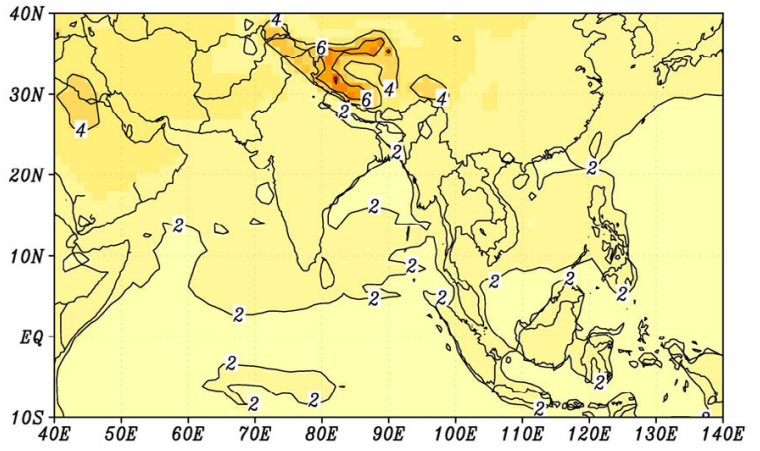

(d)

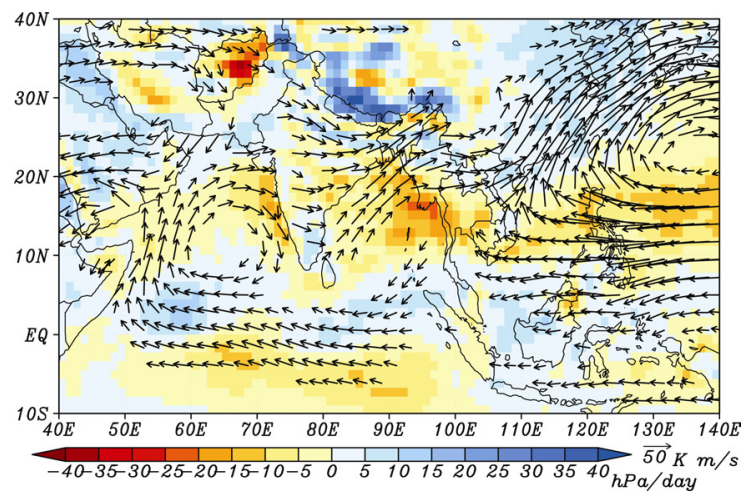

図-1（a) 6 月から 9 月における標準実験のアンサンブル平均の降水と850hPa高度の水平風.

予測された平均場の変化: (b) $2 \mathrm{~m}$ 気温, (c) 降水と $850 \mathrm{hPa}$ 高度の水平風，(d) 鋁直積算水蒸気フラックスと $500 \mathrm{hPa}$ 鉛直流.

(a) に示される四角は，図-2, 3, 4, 5 で用いられた解析領域 (8.5-30N, 65-100E). (b) の2m気温の変化は，信頼水準99\%を 超えた変化である. (c) の着色部分は, 信頼水準 $95 \%$ 超える降水の変化を示し，灰色と黒のベクトルは，それぞれ $0.5 と$ $1.0 \mathrm{~m} / \mathrm{s}$ を越える風速の変化を示寸. (d) のベクトルは, $2.0 \times 10^{4} \mathrm{~m} / \mathrm{s}$ 以上の水蒸気フラックスの変化を示寸.

表-1 観測とアンサンブル実験のモンスーンインデックス

\begin{tabular}{ccccc}
\hline & \multicolumn{2}{c}{ Precipitato in $(\mathrm{mm} /$ day) } & U-shear $(\mathrm{m} / \mathrm{s})$ & V-shear $(\mathrm{m} / \mathrm{s})$ \\
\hline Obervation & 6.54 & 6.27 & 23.27 & 5.27 \\
Oontrol & 7.74 & 8.00 & 22.31 & 4.25 \\
2)002 & 8.16 & 8.97 & 20.65 & 3.85 \\
Ohange & $0.42\left(3.36 \%^{*}\right.$ & $0.97(9.93 \%)^{*}$ & $-1.66(-7.46 \%)^{*}$ & $-0.40(-9.31 \%)^{*}$
\end{tabular}$* 99 \%$ 信頼水淮

注 : 観測の降水は1997-2003年のGPCP 1DDを用いた。観測のU，Vシアーは，1989-2001年の水平解像度T106のERA40から計算.

徵的な循環場（対流圈上層の強い東風，下層の強い西 風）や降水分布を比較的良く再現出来ている（図省略）. $2 \mathrm{~m}$ 気温は, $\mathrm{CO}_{2}$ 倍増時に2度から6度の昇温が予測される。 海洋上よりも，チベット高原のような陸域においてより 高い昇温が見られる（図-1 (b)) 。図-1 (c) は，対流圈下 層のモンスーン循環の北への移動と, 南アジア陸上にお ける降水の顕著な増加を示している. これらの変化は, 過去の研究において示されたものと定性的な一致が見ら れる(5),6,7,8).

この領域における蒸発の増加（図省略）は，地域的な 水蒸気供給を増加させる. 温暖化した大気中における水 蒸気量の増加によって, 水蒸気フラックスは増加し, 南 アジア夏季モンスーンによる陸上の降水を増加させる (図-1 (c), 図-1 (d) ).

表-1にモンスーンのインデックスを示寸．IR-rainはイ
ンド付近 $\left(8.5-30^{\circ} \mathrm{N}, 65-100^{\circ} \mathrm{E}\right)$ における領域平均降水量 であり，IB-rainは同じ領域の陸上だけで計算した值であ る ${ }^{17)}$ 。観測データには，1997-2003 年の GPCP 1DD

( Global Precipitation Climatology Project One-Degree Daily） ${ }^{18)}$ 用いた. 数值実験のモンスーンインデックス は，標準実験と温暖化実験それぞれでアンサンブル平均 值を計算した．標準実験の降水は，観測に比べ過大評価 となっている. 温暖化時のIR-rain とIB-rainの変化は，そ れぞれ3.36，9.93\%であった.

表-1右側に風のシアーに関する 2 つの力学的インデッ クスを示す. ウォーカー循環に関係したインド洋上

(Equator-20N, 40-110）における6月から9月の850と $200 \mathrm{hPa}$ の東西風の鉛直シアー (U-shear) ${ }^{19)}$ と，インドと 東南アジア地域（10-30 $\left.\mathrm{N}, 70-110^{\circ} \mathrm{E}\right)$ におけるハドレー 循環に関係した南北風の鉛直シアー (V-shear) ${ }^{20)}$ である. 
標準実験のインデックスは，観測と良い対応を示してい る. 温暖化時の東西風シアーと南北風シアーの変化は, それぞれ-7.46と-9.31\%である. 2つの力学的インデック スの変化から，温暖化時の夏季モンスーンに関係した大 規模な循環の弱まりが示唆される.これらのインデック スの変化は，主にインドや熱帯インド洋における平均的 収束場の移動によって生じている．温暖化などの気候変 動の影響によって循環場の位置が変化するような場合に は，現在の地理的に不動のモンスーンインデックスは， 適切な尺度ではないかもしれない"

\section{5. 日降水の変化に対する力学的, 熱力学的効果}

ここでは，6月から9月の夏季南アジア陸上（8.5-30N， 65-100 E) における日降水の変化について解析を行う.

図-2は日降水の頻度分布を示す，標準実験で計算され た日降水頻度は，20-30mm/dayのやや強い降水と極端に 強い降水（60mm/day以上）の頻度がGPCP 1DDに比べて 過大であるが，概ね良く一致している．西太平洋域や中 国を含む東アジア地域など極端な降水イベントもよく再 現できている地域もある ${ }^{15)}$. 極端な降水イベントについ ての限られた再現性の原因の一端は観測の不足にある. なぜならば，日降水の地上雨量観測は人口が多い限られ た陸上に集中しているからである，例えば，山岳地域に おける観測は非常に限られているため, 地形による降水 の変動（地形性降雨）は大きなバイアスやランダム誤差 の原因の一つである ${ }^{21), 22)}$. 図-2に示されるように, $\mathrm{CO}_{2}$ 倍増時においてアンサンブルの 1 標準偏差の範囲を超え る非常に強い降水（50mm/day以上）の顕著な強まりが 見られる. モデルは，定量的な妥当性について，パラメ タリゼーションの改良や観測の充実・高度化によって今 後さらに洗練されなければならないが，予測された系統 的変化についての定性的議論は十分意味がある.

図-3 (a)，3 (b) は500hPa高度における鉛直流の相対頻 度 $\left(\operatorname{Pr}_{\omega}\right)$ と，その 2 つアアサンブル実験間の差を示 したものである. 比較的強い上昇流 $(300 \mathrm{hPa} / \mathrm{day}$ 前後 $)$ は減少し、弱い上昇流（0から $150 \mathrm{hPa} /$ day） は増加する ことが予測される。比較的弱い下降流（-300から0 $\mathrm{hPa}$ /day）は減少する。このように, 鉛直流の平均值は 上昇側ヘシフトし，その分散は減少する。極端に強い上 昇流（500hPa/day以上）については僅かながらではある が，増加することが示唆される。

図-4は，ある力学場において期待される日降水強度 $\left(R_{\omega}\right)$ を示す．極端に強い上昇流の相対頻度 $\left(\operatorname{Pr}_{\omega}\right)$ は 非常に小さいけれども, 豪雨は通常強い上昇流を伴う. 温暖化時には，ある上昇流が与えられた際に期待される 降水強度に，アンサンブル実験間の 1 標準偏差の不確実 性を超える顕著な強まりがみられる。

温暖化時において，非常に強い上昇流が生じるときに 期待される降水強度の変化（500-1000hPa/dayの平均で

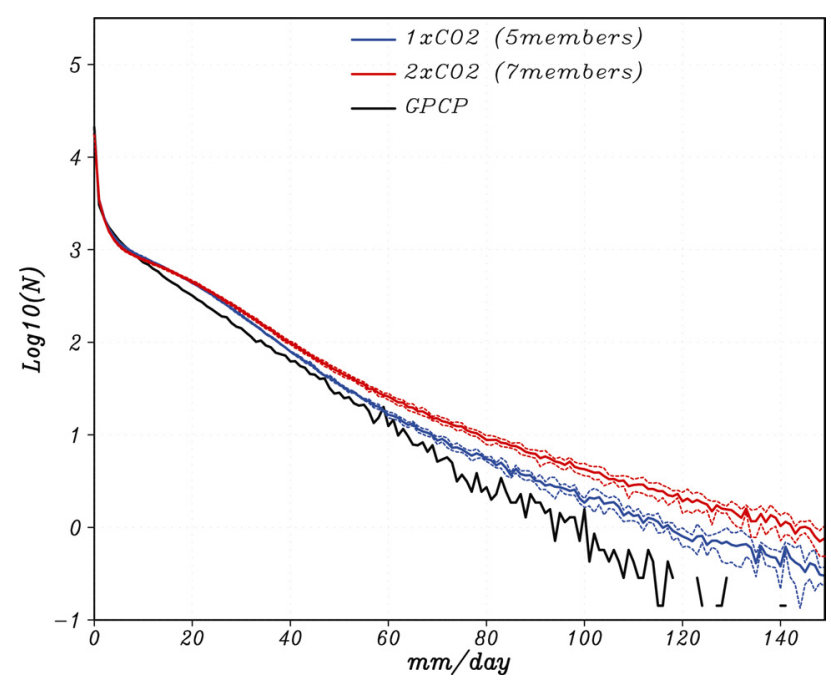

図-2６月から9月における南アジア陸上（8.5-30N, 65-100E） の日降水頻度分布. 黒の実線がGPCP 1DD (1997-2003) による観測. 青と赤の実線はそれぞれ標準実験と温暖化 実験のアンサンブル平均. 破線は, それぞれのアンサン ブル実験の標準偏差.
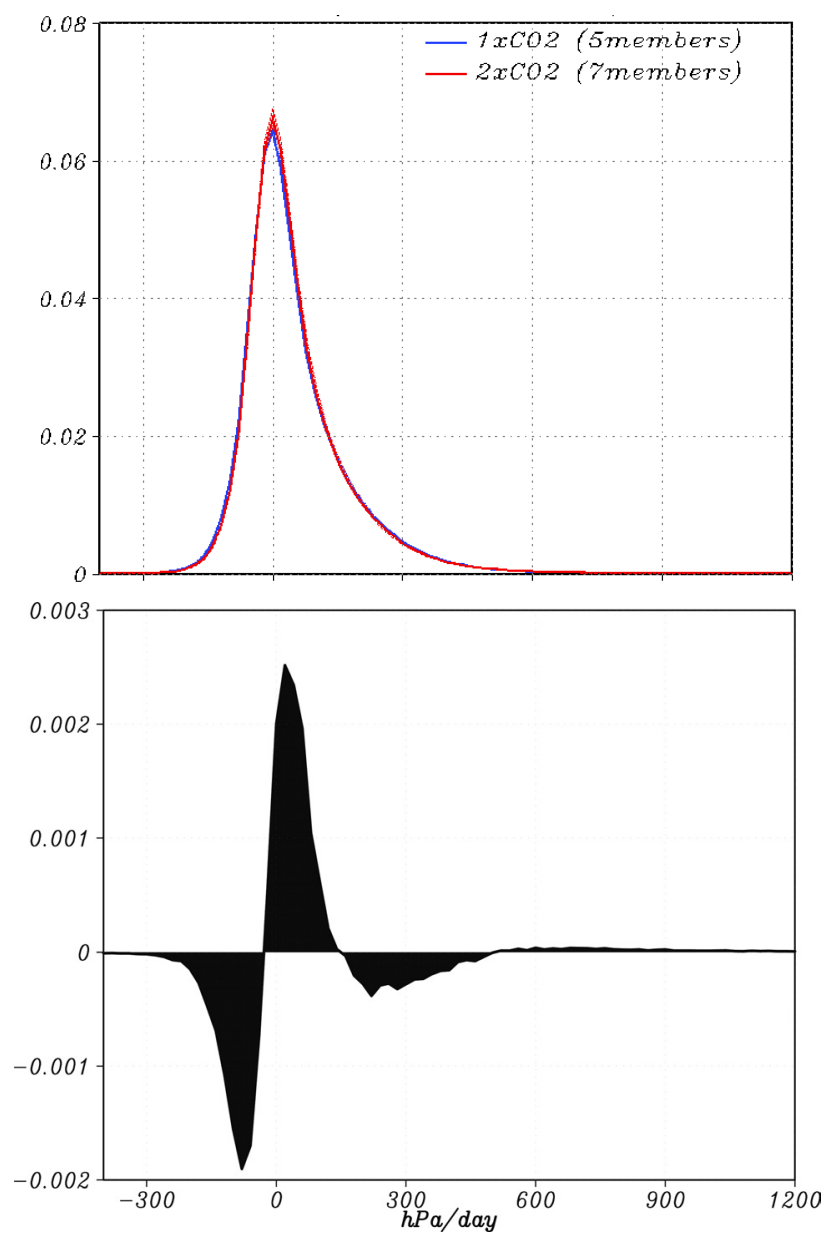

図-3 (a) $500 \mathrm{hPa}$ 高度の鉛直流（上向き）の相対頻度分布. 解 析領域と青と赤の線は図-2と同じ. (b)タイムスライスア ンサンブル実験の相対頻度分布の差. 


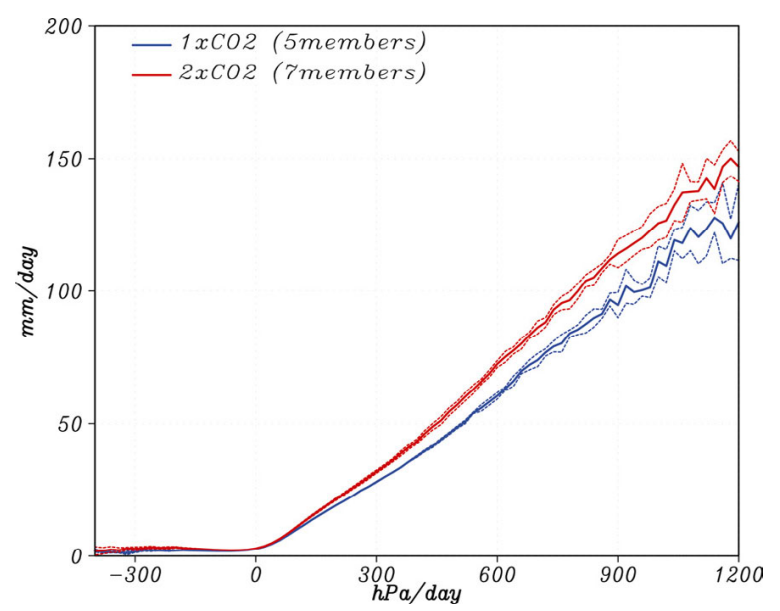

図-4 500hPa高度の鉛直流（上向き）に対して期待される日 降水強度. 解析領域，実線・破線は図-2と同様.

17.4\%）は，この解析領域における可降水量の増加 (18.9\%) とほぼ一致している。したがってこの降水強 度の変化は、大気中水蒸気の増加が主たる要因であると 考えられる (熱力学的変化).

図-5は，解析領域における温暖化時の日降水の変化に 対する力学的変化, 熱力学的变化, 相関項の寄与につい て示したものである.それぞれの項は，式（1）で定義 されている. 解析領域陸上における平均降水量の変化 (9.93\%) に対する力学的変化, 熱力学的変化, 相関項 は，それぞれ0.3, 9.64, -0.01\%であった. 南アジア夏季モ ンスーンの陸上における平均降水量の変化は, 主に熱力 学的な変化によって生じており, 力学的な影響は小さ かった．相関項の影響はほとんど無視できる.

鉛直流の強さ別に見ると，力学的変化は図-3(b)に示 される力学場の変化により, 比較的強い（弱い）上昇流 によってモンスーンの日降水を減少（増加）させている. 対照的に，熱力学的変化はほとんどすべての場合におい て日降水の増加をもたらしている。極端な上昇流

$(600 \mathrm{hPa} /$ day以上 $)$ の場合には, 力学的変化の方が熱力 学的変化よりも降水の変化に対して大きく寄与している. この力学的変化は, 図-3(b) に示される極端な上昇流の 若干の増加と関係している.

解析領域で，陸上だけでなく海上も含んだ場合は，平 均降水量の変化に対する力学的変化, 熱力学的変化, 相 関項の寄与は，それぞれ-1.87，5.55，-0.32\%であった. 力 学的変化が平均降水量の増加と日降水の強まりを抑制す るのに比較的大きな役割を果たしている. この力学的変 化は鉛直流の分散の減少と関係しており，その一部は循 環場の北へのシフトと関係したアラビア海とベンガル湾 上における高気圧性のアノマリによるものである。しか し，依然として夏季モンスーンの日降水の強まりの主要 因は熱力学的変化であった.

\section{6. まとめ}

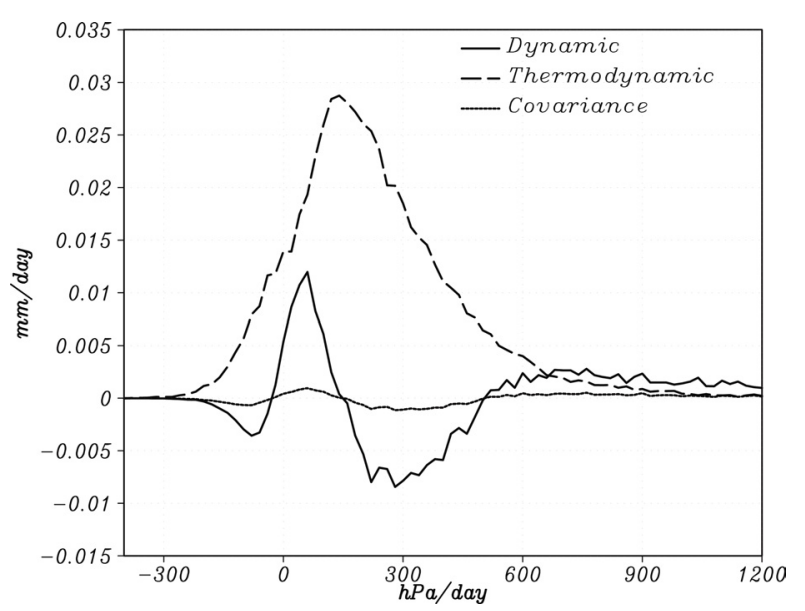

図-5 温暖化時の日降水の変化に対寸る力学的変化，熱力学 的変化, 相関項. 解析領域は図-2と同じ. 実線は力学 的変化, 破線は熱力学的変化, 点線は相関項.

南アジア地域における循環場の北へのシフトが大規模 スケールのモンスーンインデックスを弱めていた. この 循環場の移動は，温暖化時における海陸の熱的コントラ ストの強化と，熱帯太平洋におけるエルニーニョに似た 温暖化パターンによってハドレー・ウォーカー循環が変 調していることに起因すると考えられる，ただし，エル ニーニョに似た海面水温パターンは，全てのモデルに見 られたわけではない(図省略).

非常に強い上昇流の時の日降水強度の変化は，可降水 量の増加とほぼ一致していた（熱力学的変化）。しかし ながら，南アジア陸上において，極端な降水現象に対す る力学的変化の寄与は熱力学的効果を上回っていた.

湿潤対流が卓越する熱帯地域においては， $\mathrm{CO}_{2}$ の増加 に応答して対流圈上層における正味の放射冷却の増加, 地表における正味の放射加熱の増加, 大気中水蒸気の増 加，上向き潜熱輸送の強まりなどの変化が起き，対流圏 上層の温暖化によって乾燥大気の静的安定度が強まる (図省略)。安定度の強まりは解析領域の多くの地域に おいて鉛直流の分散を抑制する。このような乾燥大気の 静的安定度の変化にもかかわらず，チベット高原の南斜 面のような山岳地域近くにおいては，モンスーン循環の 北へのシフトに関係していると考えられる非常に強い上 昇流の強化が見られる.これがこの地域における極端な 降水現象の強まりを引き起こしている（力学的効果）.

高解像度気候モデルによるアンサンブル実験結果から 顕著な降水の変化が示唆された. しかしながら, 大気一 海洋の結合が夏季アジアモンスーンにとって非常に重要 な特徵であり，海面水温を与えた大気モデルによる実験 と大気一海洋結合実験の間には，大きな相違が見られる ことが指摘されている23), 24). 本研究の結果の信頼性につ いては, 高解像度大気・海洋結合モデル, もしくは海洋 混合層モデルと結合した大気大循環モデルによるアンサ ンブル実験, 複数のモデルによるマルチモデルアンサン 
ブルによってさらなる評価を行う必要があると考える.

謝辞 : 本研究は，環境省地球環境研究総合推進費「極 端な気象現象を含む高解像度気候変化シナリオを用いた 温暖化影響評価研究（B-12）」（代表 : 江守正多 国立 環境研究所）の一部として行われました。数值シミュ レーションは，文部科学省の人・自然・地球共生プロ ジェクト「高分解能大気海洋モデルを用いた地球温暖化 予測に関する研究」において，地球シミュレータを利用 して行われました．東京大学気候システムセンターの木 本昌秀教授には，大変有益なコメントを頂きました.

\section{参考文献}

1) Easterling, D. R., Meehl, G. A., Parmesan, C., Changnon, S. A., Karl, T. R. and Mearns, L. O.: Climate Extremes: Observations, Modeling, and Impacts, Science, Vol.289, pp.2068-2074, 2000.

2) IPCC: Climate Change 2001: Impacts, Adaptation \& Vulnerability. Contribution of Working Group II to the Third Assessment Report of the Intergovernmental Panel on Climate Change, McCarthy, J. J., Canziani, O. F., Leary, N. A., Dokken, D. J., and White, K. S. eds., Cambridge University Press, Cambridge, UK., pp.1000, 2001.

3) Meehl, G. A., and Washington, W. M.: South Asian summer monsoon variability in a model with doubled atmospheric carbon dioxide concentration, Science, Vol.260, pp.1101-1104, 1993.

4) Meehl, G. A., and Arblaster, J. M.: Mechanisms for projected future changes in south Asian monsoon precipitation, Clim. Dyn., Vol.21, pp. 659-675, doi:10.1007/s00382-003-0343-3, 2003.

5) Bhaskaran, B., Mitchell, J. F. B., Lavery, J. R., and Lal, M.: Climatic response of the Indian subcontinent to doubled $\mathrm{CO}_{2}$ concentrations, Int. J. Climatol., Vol.15, pp.873-892, 1995.

6) Kitoh, A., Yukimoto, S., Noda, A., and Motoi, T.: Simulated changes in the Asian summer monsoon at times of increased atmospheric $\mathrm{CO}_{2}$, J. Met. Soc. Japan, Vol.75, pp.1019-1031, 1997.

7) Hu, Z. -Z., Latif, M., Roeckner, E., and Bengtsson, L.: Intensified Asian summer monsoon and its variability in a coupled model forced by increasing greenhouse gas concentrations, Geophys. Res. Lett., Vol.27, pp.2681-2684, 2000GL01155, 2000.

8) Ashrit, R. G., Douville, H., and Rupa Kumar, K.: Response of the Indian monsoon and ENSO-monsoon teleconnection to enhanced greenhouse effect in the CNRM coupled model, J. Met. Soc. Japan, Vol.81, pp.779-803, 2003.

9) Douville, H., Royer, J. -F., Polcher, J., Cox, P. M., Gedeney, N., Stephenson, D. B., and Valdes, P. J.: Impact of $\mathrm{CO}_{2}$ doubling on the Asian summer monsoon: Robust versus model-dependent responses, J. Meteorol. Soc. Japan, Vol.78, pp.421-439, 2000.

10) May, W.: Potential future changes in the Indian summer monsoon due to greenhouse warming: analysis of mechanisms in a global time-slice experiment, Clim. Dyn., Vol.22, pp.389-414, doi:10.1007/s00382-003-0389-2, 2004.
11) Mitchell, J. F. B., and Johns, T. C.: On modification of global warming by sulfate aerosols, J. Clim., Vol.10, pp.245-267, 1997.

12) May, W.: Simulation of the variability and extremes of daily rainfall during the Indian summer monsoon for present and future times in a global time-slice experiment, Clim. Dyn., Vol.22, pp.183204, doi:10.1007/s00382-003-0373-x, 2004.

13) Emori, S., Hasegawa, A., Suzuki, T., and Dairaku, K.: Validation, parameterization dependence and future projection of daily precipitation simulated with a high-resolution atmospheric GCM, Geophys. Res. Lett., Vol.32, L06708, doi:10.1029/2004GL022306, 2005.

14) Rayner, N. A., Parker, D. E., Horton, E. B., Folland, C. K., Alexander, L. V., Rowell, D. P., Kent, E. C., and Kaplan, A.: Global analyses of sea surface temperature, sea ice, and night marine air temperature since the late nineteenth century, J. Geophys. Res., Vol.108, No.D14, 4407, doi:10.1029/2002JD002670, 2003.

15) 大楽浩司, 江守正多：温暖化時の降水の極值現象の変化と そのメカニズムの考察, 平成16年度「異常気象と長期変動」 研究集会報告, pp.85-94, 2004.

16) Emori, S., and Brown, S. J.: Dynamic and thermodynamic changes in mean and extreme precipitation under changed climate, Geophys. Res. Lett., in press.

17) Sontakke, N. A., Plant, G. B., and Singh, N.: Construction of all India rainfall series for the period 1844-1991, J. Clim, Vol.6, pp.1807-1811, 1993.

18) Huffman, G. J., Adler, R. F., Morrissey, M. M., Bolvin, D. T., Curtis, S., Joyce, R., McGavock, B., and Susskind, J.: Global precipitation at one-degree daily resolution from multisatellite observations, J. Hydrometeor., Vol.2, pp.36-50, 2001.

19) Webster, P. J., and Yang, S.: Monsoon and ENSO: Selectively interactive systems, Quart. J. Roy. Meteor. Soc., Vol.118, pp.877926, 1992.

20) Goswami, B. N., Krishnamurthy, V., and Annamalai, H.: A broad scale circulation index for interannual variability of the Indian summer monsoon, Quart. J. Roy. Meteor. Soc., Vol.125, pp.611-633, 1999.

21) Xie, P., and Arkin, P. A.: Global Precipitation: A 17-Year Monthly Analysis Based on Gauge Observations, Satellite Estimates, and Numerical Model Outputs, Bull. Amer. Meteor. Soc., Vol.78, pp.2539-2558, 1997.

22) Dairaku, K., Emori, S., and Oki, T.: Rainfall amount, intensity, duration, and frequency relationships in the Mae Chaem watershed in Southeast Asia, J. Hydrometeor., Vol.5, No.3, pp.458-470, 2004.

23) Douville, H.: Limitations of time-slice experiments for predicting regional climate change over South Asia, Clim. Dyn., Vol.24, pp.373-391, 2005.

24) Inatsu, M., and Kimoto, M.: Difference of boreal summer climate between coupled and atmosphere-only GCMs, SOLA, in press.

(2005. 9. 30受付) 